\title{
Calculated characters of leaves are independent on environmental conditions in Salix herbacea (Salicaceae) and Betula nana (Betulaceae)
}

\author{
Katarzyna Marcysiak* \\ Department of Botany, Kazimierz Wielki University, Ossolińskich 12, 85-093 Bydgoszzz, Poland
}

\section{Abstract}

The goal of the study was to check if the shape-describing characters, calculated as ratios of the morphological measured traits are more stable, compared to the latter, and can be treated as independent on environmental conditions. The test was based on the example of leaves of Salix herbacea and Betula nana. The individuals of the two populations of S. herbacea from Tatra Mts. were divided into two groups: with bigger and smaller leaves. The two populations of $B$. nana came from different substrata: the first one, collected from the mire on the lower altitude, had bigger leaves, and the second, collected from the granite plateau and higher altitude, had smaller leaves.

For both species, the measured traits were generally more variable than the ratios calculated on their basis, as expressed by the variation coefficients. The results of Students' t-test analyses showed statistically significant differences between the two groups of $S$. herbacea and the two populations of $B$. nana with respect to almost all the measured characters, and no such differences for the calculated traits, reflecting the leaf shape.

As the differentiation of the leaf size was probably bound to the environmental factors, the lack of the dependence of the leaf shape on the leaf size could lead to a conclusion of independence of the leaf shape on the environment conditions.

Keywords: morphologic characters, synthetic characters, Salix herbacea, Betula nana

\section{Introduction}

Morphological traits are basic for the description of a plant. Recently, their role has been decreasing in the face of rapid development of molecular biology and modern methods of DNA analysis, treated as more reliable and more sensitive, especially for reflecting the intra- and inter-populational diversity [1,2]. Still, morphological characters remain important, as they are crucial for the identification of taxa. Various kinds of morphological features, concerning both vegetative and generative organs, are still used in taxonomic studies and analysis of diversity [3-10]. The main criticism of morphological characters is connected with their dependence on changing environmental factors, such as precipitation, temperature, insolation [11-15]. The proposed solution is to use synthetic characters, describing rather the shape of the plant structures, than the size, being regarded as much more stable [5].

The goal of the present study is to test whether the shapedescribing characters are more stable and can be treated as

\footnotetext{
*Email: marc@ukw.edu.pl
}

This is an Open Access digital version of the article distributed under the terms of the Creative Commons Attribution 3.0 License (creativecommons.org/licenses/by/3.0/), which permits redistribution, commercial and non-commercial, provided that the article is properly cited. independent on environment when compared to measured traits, on the example of leaves. The assumption was that the variability of the measured morphological traits would be greater than in the case of shape describing characters. It was also expected that individuals of various leaf size, sampled in the same geographical region, should not show statistically significant differences with regard to synthetic, shape-describing traits. If the differentiation of the leaf size can be bound with environmental factors, the independence of the leaf shape on the leaf size may lead to a conclusion of independence of the leaf shape of the environmental conditions.

To check the hypothesis, the leaves of two taxonomically unrelated species, interesting as subjects of different biological studies, were examined: Salix herbacea L. (Salicaceae) and Betula nana L. (Betulaceae).

\section{Material and methods}

\section{Species decriptions}

Salix herbacea, an arctic-alpine dwarf shrub, is relatively well known [16-23]. Its genetic diversity and phylogeography has been lately characterized by Alsos et al. [24]. The willow has been also interesting as an important fossil material, but recently it has gained more attention as a possibly endangered species in the perspective of the climate warming. Still, a thorough examination of its morphological variability in the whole range is lacking. In the Tatra Mountains, two morphological 
types, differing with regard to the leaf size, have been reported: besides the typical form, f. macrophylla Sér. having leaves 23-27 mm long [25].

Betula nana is a small, circum-boreal shrub. In its southernmost localities the birch forms small, relic populations, while in the northern part of the species range it is important as one of few, if not the only one, woody plants [26-28]. Studies on Betula nana focused on its occurrence in the early Holocene floras [29-31], hybridization with Betula pubescens [28,32-36] and importance in forming the mountain birch (Betula pubescens var. tortuosa) [32-38]. In Scandinavia, B. nana builds vast populations and shows low morphological variation. However, the morphological differences between tundra and mire populations, as well as decreasing of the leaf size in severe climatic conditions, were described [28]. The relation of the leaf size to altitude for other birch species was also reported [39].

\section{Measurements and analysis}

For each taxon, samples from two populations were analyzed, a sample consisted of approximately 30 specimens, for every specimen 5-10 leaves were collected. Individuals growing no closer than $3 \mathrm{~m}$ to each other were selected, to avoid sampling the same genet. The location of sampled populations are given in Tab. 1.

Measurements were taken on the dried material. Leaves were scanned and then the scans were measured with digiShape 1.9.177 (Cortex Nova), teeth were counted from the scans and synthetic traits were calculated (Tab. 2, Tab. 3).

To find possible two morphological types of leaves of Salix herbacea in the Tatra Mountains [25], the k-means method of the cluster analysis was used, on the basis of means of individuals of two populations together. For comparisons between two distinguished groups of the willow and between two populations of the dwarf birch, Student' t-test was performed. The deviation of means of traits was checked on the box and whiskers graphs and the variation coefficients were calculated. For all calculations and analysis STATISTICA 9.0 (StatSoft, Inc.) was used.

\section{Results}

K-mean clustering allows distinguishing two groups of 60 individuals of Salix herbacea: group A with bigger leaves, and group B having smaller leaves, consisting of 23 and 37 individuals, respectively (Fig. 1a, Tab. 2).

For Salix herbacea, the values of the variation coefficients, calculated for characters describing the leaf size (Tab. 2) reached more than $15 \%$, while for characters illustrating the leaf shape only up to $10 \%$, with the exception of the character $12(19.21 \%)$. The number of teeth (character 6$)$ and the number of teeth/perimeter (character 13) had variation coefficients about $20 \%$. The coefficient of the petiole length (character 3) was highest (almost 30\%; Fig. 2).

Leaves traits of Betula nana were generally less variable. For characters $1-5$ the coefficient values ranged from 10.53 to $22.27 \%$, for characters $7-11$ - from 4.11 to $6.94 \%$, for the character 12, it equaled $14.71 \%$ and for character 6 and 13 , $14.98 \%$ and $14.06 \%$, respectively. Again, the petiole length (character 3) was the most variable trait, with the variation coefficient: $22.27 \%$ (Fig. 2).

The analyses of characters' means and standard deviations values gave analogical findings, as they are shown for the example of Salix herbacea only (Fig. 1a-c).

Two groups of Salix herbacea individuals were created on the basis of measured characters (1-5), so in the t-test these features differed the groups statistically significantly, as well as the number of teeth (6). All synthetic traits, characterizing the shape of leaves (7-12) and the leaf margin (13), showed no statistically significant differences (Tab. 2).

In the case of the dwarf birch, the t-test showed statistically significant differences for traits: 1-2 and 4-6. From among the measured characters, only the petiole length (3) did not differ the populations significantly. The differences found for the synthetic traits were not significant, with the exception of character 13 (Tab. 3).

\section{Discussion}

Although within the two studied populations of Salix herbacea in the Tatras, the form macrophylla was not found, the individuals created two distinct groups. Their values of the leaf length and width were within the limits described in European and local floras $[18,26,40]$. Still, the differences between the groups with the respect to leaves sizes were great enough to be statistically significant. The morphological variability of Salix herbacea was seldom characterized, only the stomatal index was thoroughly studied $[19,20,41,42]$. Wijk $[16,17]$ reported some correlations between the biomass, the density and the cover of the species in relation to the longevity of the snow cover, as well as the influence of the growing season length on the shoot increment. The material for the present study was not collected in one year (Tab. 1) and the share of the distinguished groups in populations varied. Within the population Sh1, six individuals belonged to the group A (bigger leaves) and 23 to B (smaller leaves), while in the population Sh2, 17 and 14 , respectively. This dissimilarity could have been caused by different climatic conditions in particular years. What should be emphasized, the results of Students' t-test analyses for the two groups fulfilled the assumption that the measured traits differed them significantly, while the synthetic ones did not.

Tab. 1 Location of analyzed populations of Salix herbacea and Betula nana.

\begin{tabular}{|c|c|c|c|c|c|c|c|}
\hline Acronym & Taxon & Locality and character of a site & $\begin{array}{c}\text { No. of } \\
\text { individuals }\end{array}$ & Alt. & Longitude & Latitude & $\begin{array}{c}\text { Year of } \\
\text { collection }\end{array}$ \\
\hline Sh1 & Salix herbacea & Poland, Tatra Mts., Świnicka Przełęcz (granite slopes) & 29 & 2000 & $20^{\circ} 00.38^{\prime}$ & $49^{\circ} 13.08^{\prime}$ & 2005 \\
\hline Sh2 & Salix herbacea & Poland, Tatra Mts., slopes of Rysy (granite slopes) & 31 & 1997 & $20^{\circ} 04.86^{\prime}$ & $49^{\circ} 10.45^{\prime}$ & 2008 \\
\hline Bn1 & Betula nana & Norway, Buskerud, Geilo (mire) & 33 & 800 & $8^{\circ} 12.41^{\prime}$ & $60^{\circ} 32.08^{\prime}$ & 2006 \\
\hline $\mathrm{Bn} 2$ & Betula nana & Norway, Buskerud, Geilo, Ustetind (granite plateau) & 32 & 1200 & $8^{\circ} 00.10^{\prime}$ & $60^{\circ} 27.38^{\prime}$ & 2006 \\
\hline
\end{tabular}


Tab. 2 Results of t-test for 2 groups of Salix herbacea.

\begin{tabular}{|c|c|c|c|c|c|c|c|}
\hline No. & Character & Character describes & Group A & Group B & $t$ & $d f$ & $p$ \\
\hline & Perimeter of a leaf blade $(\mathrm{mm})$ & leaf size & 54.77 & 42.22 & -10.23 & 58 & 0.000 \\
\hline & Length of a leaf blade (mm) & leaf size & 18.56 & 14.44 & -9.66 & 58 & 0.000 \\
\hline & Length of a petiole $(\mathrm{mm})$ & leaf size & 2.82 & 1.98 & -5.69 & 58 & 0.000 \\
\hline 4. & Width of a leaf blade measured at $1 / 2$ of its length $(\mathrm{mm})$ & leaf size & 14.13 & 10.58 & -9.29 & 58 & 0.000 \\
\hline 5. & Width of a leaf blade measured at $1 / 4$ of its length (mm) & leaf size & 12.94 & 9.71 & -8.740 & 58 & 0.000 \\
\hline 6. & Number of teeth on a leaf blade margin & leaf blade margin & 35.06 & 30.77 & -2.68 & 58 & 0.009 \\
\hline 7. & Apex angle of a leaf blade $\left(^{\circ}\right)$ & leaf shape & 169.89 & 165.11 & -1.22 & 58 & 0.228 \\
\hline & Base angle of o leaf blade $\left(^{\circ}\right)$ & leaf shape & 155.17 & 150.75 & -1.10 & 58 & 0.277 \\
\hline & Ratio of perimeter/length (character 1/character 2) & leaf shape & 2.95 & 2.93 & -0.63 & 58 & 0.530 \\
\hline 10. & Ratio of length/width at $1 / 2$ (character $2 /$ character 4$)$ & leaf shape & 1.33 & 1.38 & 1.58 & 58 & 0.119 \\
\hline 11. & Ratio of width at $1 / 4$ and $1 / 2$ (character $4 /$ character 5 ) & leaf shape & 0.92 & 0.92 & 0.08 & 58 & 0.933 \\
\hline & $\begin{array}{l}\text { Ratio of length of a petiole/sum of blade and petiole length } \\
\text { [character } 3 /(\text { character } 2+\text { character } 3)]\end{array}$ & leaf shape & 0.13 & 0.12 & -1.94 & 58 & 0.057 \\
\hline 13. & Ratio of number of teeth/perimeter (character $6 /$ character 1 ) & leaf blade margin & 0.65 & 0.74 & 2.52 & 58 & 0.014 \\
\hline
\end{tabular}

Nos. 1-6 represent differences statistically significant at $p<0.01$.

Tab. 3 Results of t-test for 2 populations of Betula nana.

\begin{tabular}{|c|c|c|c|c|c|c|c|}
\hline No. & Character & Character describes & Bn1 & Bn2 & $t$ & $d f$ & $p$ \\
\hline & Perimeter of a leaf blade $(\mathrm{mm})$ & leaf size & 31.28 & 28.28 & 3.69 & 63 & 0,000 \\
\hline & Length of a leaf blade (mm) & leaf size & 8.22 & 7.41 & 3.64 & 63 & 0.000 \\
\hline & Length of a petiole $(\mathrm{mm})$ & leaf size & 1.78 & 1.55 & 2.49 & 63 & 0.015 \\
\hline 4. & Width of a leaf blade measured at $1 / 2$ of its length $(\mathrm{mm})$ & leaf size & 8.47 & 7.76 & 3.67 & 63 & 0.000 \\
\hline 5. & Width of a leaf blade measured at $1 / 4$ of its length $(\mathrm{mm})$ & leaf size & 7.35 & 6.63 & 3.83 & 63 & 0.000 \\
\hline 6. & Number of teeth on a leaf blade margin & leaf blade margin & 15.69 & 12.92 & 6.80 & 63 & 0.000 \\
\hline & Apex angle of a leaf blade $\left(^{\circ}\right)$ & leaf shape & 165.14 & 161.22 & 2.44 & 63 & 0.017 \\
\hline 8. & Base angle of o leaf blade $\left(^{\circ}\right)$ & leaf shape & 165.06 & 163.74 & 0.54 & 63 & 0.592 \\
\hline & Ratio of perimeter/length (character 1/character 2) & leaf shape & 3.82 & 3.83 & -0.13 & 63 & 0.900 \\
\hline 10. & Ratio of length/width at $1 / 2$ (character $2 /$ character 4$)$ & leaf shape & 0.97 & 0.96 & 0.78 & 63 & 0.440 \\
\hline 11. & Ratio of width at $1 / 4$ and $1 / 2($ character $4 /$ character 5$)$ & leaf shape & 0.87 & 0.86 & 1.29 & 63 & 0.203 \\
\hline 12. & $\begin{array}{l}\text { Ratio of length of a petiole/sum of blade and petiole length } \\
\text { [character } 3 /(\text { character } 2+\text { character } 3)]\end{array}$ & leaf shape & 0.18 & 0.17 & 0.55 & 63 & 0.584 \\
\hline & Ratio of number of teeth/perimeter (character 6/character 1 ) & leaf blade margin & 0.51 & 0.46 & 3.07 & 63 & 0.003 \\
\hline
\end{tabular}

Nos. 1, 2, 4-6, 13 represent differences statistically significant at $p<0.01$.

In the case of Betula nana the results were not so clear, although similar. It should be underlined that the two compared populations of the birch grew on different substrata: population $\mathrm{Bn} 1$ on the mire, while population $\mathrm{Bn} 2$ on the granite mountain plateau (Tab. 1). The populations were not much distant but their altitude also differed: the mire (population $\mathrm{Bn} 1)$ lied $800 \mathrm{~m}$ a.s.l., and the plateau (Bn2) - $1200 \mathrm{~m}$ a.s.l. The differences between the leaf sizes of these two samples were statistically significant, with the exception of the petiole length. The smaller leaf size on the plateau could be explained by the influence of the substratum, or of the more severe climatic conditions, as reported by de Groot et al. [28]. Białobrzeska and Truchanowicz [39] also found a tendency for the leaf size to decrease with increasing altitude in their studies on the Betula pubescens/carpatica in the Stołowe Mountains in Poland. They also indicated the importance of the insolation for the leaf size, but in the present study both populations growth on the plain ground, under similar exposure conditions. On the other hand, Kovačić and Nikolić [43] described poor correlations between ecological factors and Betula pendula leaf shape and size in Croatia.

It should be emphasized that the two populations of the dwarf birch, growing in various environmental conditions, but geographically close, differed statistically significantly in respects of the leaf size, but not of the synthetic characters describing leaf shape. This can be regarded as a proof of independence of the leaf shape of the environmental conditions, at least for the species studied.

Other interesting findings of the present study are similar proportions of variability of the same characters between 


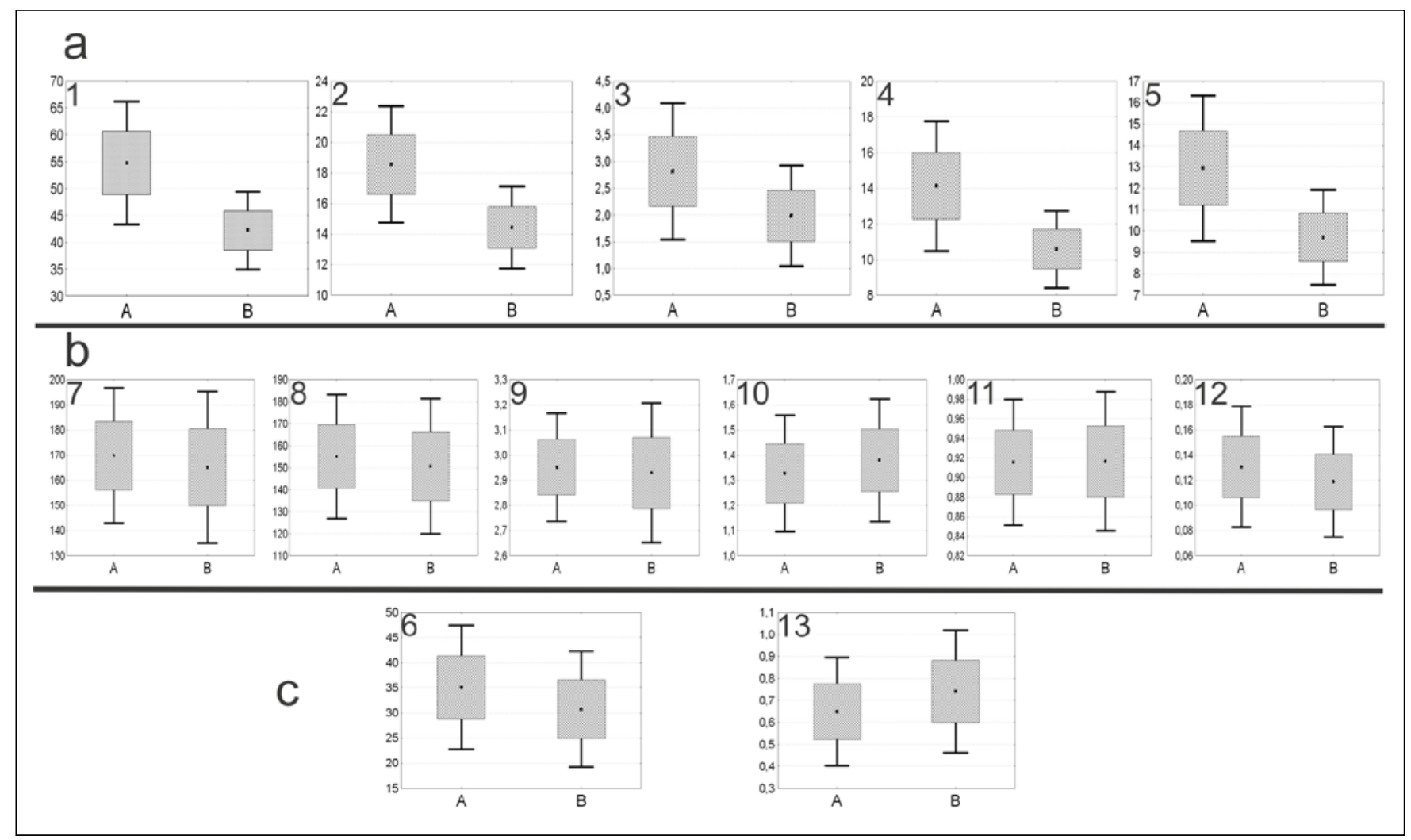

Fig. 1 Analyses of S. herbacea characters means for two groups: A - bigger leaves; B - smaller leaves. a Characters describing the leaf size. b Characters describing the leaf shape. $\mathbf{c}$ Characters describing the leaf blade margin. According to Tab. 2, numbers of characters, are given in left upper corners. Point - arithmetic mean; box - standard deviation; whiskers - 1.96 standard deviation.

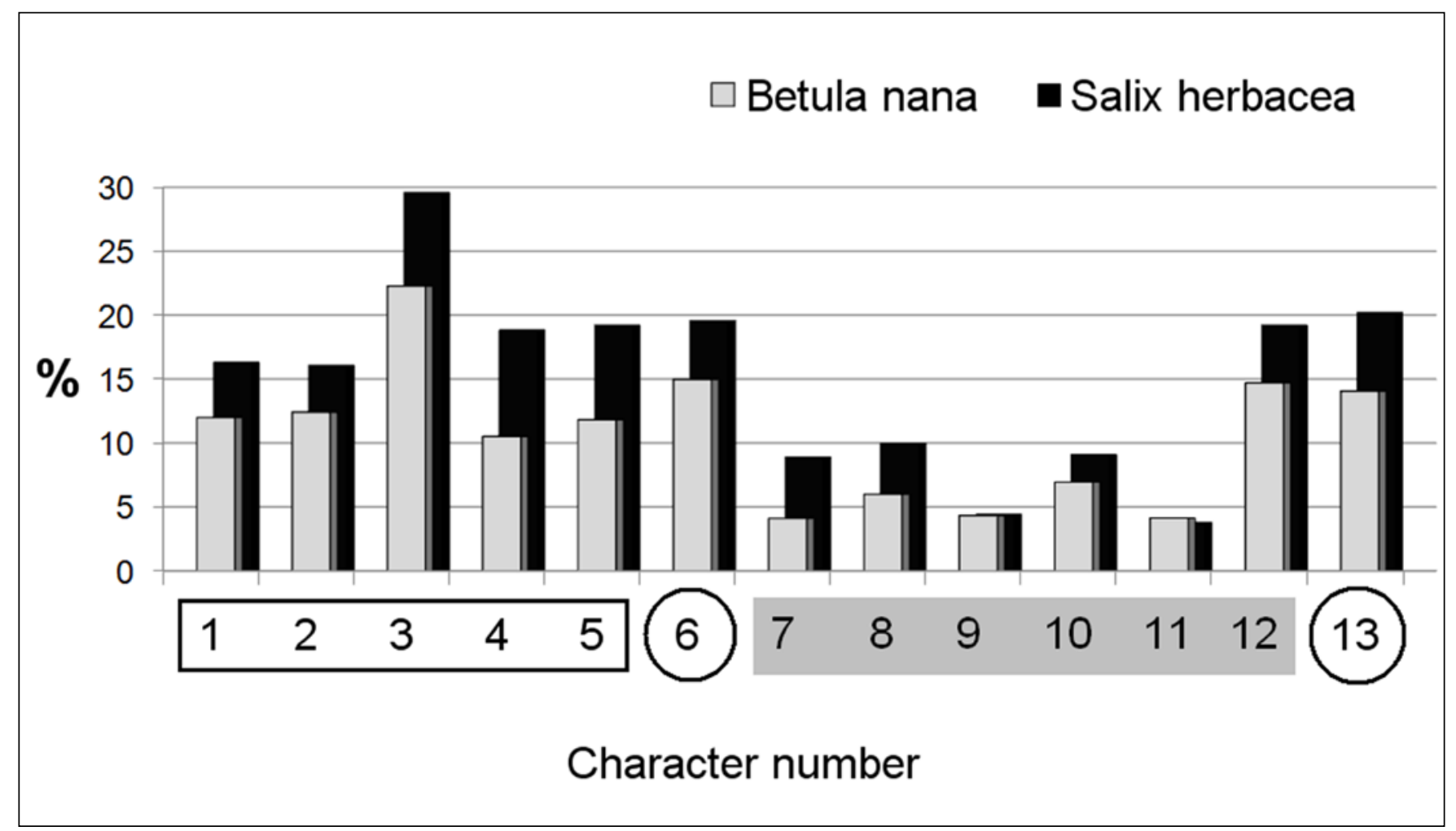

Fig. 2 Coefficients of variation for S. herbacea and B. nana. Character numbers according to Tab. 2: frame - characters describing the leaf size; shade - characters describing the leaf shape; circles - characters describing the leaf blade margin. 
the two species (Fig. 2). The most variable character in both shrubs is the petiole length, and this value divided by the sum of the blade and petiole lengths (i.e. character 12) is one of the two most variable synthetic characters. For both species, the measured features are more variable than the calculated ones, with the exceptions of the previously mentioned character 12 , and character 13. The latter describes the margin of the leaf blade and is calculated as the number of teeth (6) divided by the perimeter (1), so the resulting character shows the number of teeth per $1 \mathrm{~mm}$. Both source characters are moderately variable, and the variation coefficients of character 13 calculated on their basis is very close to that of character 6 . Thus the variability of the number of teeth and of the number of teeth per $1 \mathrm{~mm}$ is almost the same for both species. What is more, the variation coefficients of abovementioned ratios (characters 12 and 13) have almost the same values for both species but this might be accidental.

The higher variability of the petiole length may be just characteristic for this trait, but it also may be a result a measurement technique: some petioles are slightly curved, while measurements are taken along the straight line. Petioles are too short and their curves too weak to be detected. At the same time, the higher variability of the calculated trait 13 (number of teeth per $1 \mathrm{~mm}$ ) could not be explained by the methods used and so seem to be a typical characteristic of the leaves of both species.

It can be concluded that the study allowed to confirm the hypothesis that calculated ratios are more stable than measured traits and they do not differ significantly leaves of various size. Thus probably they can be regarded as independent of changing environmental conditions, at least for the two dwarf shrubs: Salix herbacea and Betula nana.

\section{Acknowledgements}

I would like to thank Amelia Lewandowska for her great help in the measurement procedures. The collection of the material was possible thanks to the financial support of Kazimierz Wielki University in Bydgoszcz, Poland.

\section{References}

1. Levin DA. 50 years of plant speciation. In: Stuessy TF, Hörandl E, Mayer V, editors. Plant systematics: a halfcentury of progress (1950-2000) and future challenges. Vienna: International Association for Plant Taxonomy; 2001. p. 257-280.

2. Culham A. Molecular systematics: measuring and monitoring diversity. In: Leadlay E, Jury S, editors. Taxonomy and plant conservation. Cambridge: Cambridge University Press; 2006. p. 236-254.

3. Staszkiewicz J. Variability of selected shrub and tree species. Fragm Flor Geobot Polonica. 1997;2 suppl:313.

4. Max KN, Mouchaty SK, Schwaegerle KE. Allozyme and morphological variation in two subspecies of Dryas octopetala (Rosaceae) in Alaska. Am J Bot. 1999;86(11):16371644. http://dx.doi.org/10.2307/2656800

5. Kremer A, Dupouey JL, Deans JD, Cottrell J, Csaikl U, Finkeldey R, et al. Leaf morphological differentiation between Quercus robur and Quercus petraea is stable across western European mixed oak stands. Ann For
Sci. 2002;59(7):777-787. http://dx.doi.org/10.1051/ forest:2002065

6. Philipp M, Siegismund HR. What can morphology and isozymes tell us about the history of the Dryas integrifoliaoctopetala complex? Mol Ecol. 2003;12(8):2231-2242. http://dx.doi.org/10.1046/j.1365-294X.2003.01875.x

7. Greimler J, Hermanowski B, Jang CG. A re-evaluation of morphological characters in European Gentianella section Gentianella (Gentianaceae). Plant Syst Evol. 2004;248(1-4). http://dx.doi.org/10.1007/s00606-004-0171-x

8. Klimko M, Boratyńska K, Montserrat JM, Didukh Y, Romo A, Gómez D, et al. Morphological variation of Juniperus oxycedrus subsp. oxycedrus (Cupressaceae) in the Mediterranean region. Flora. 2007;202(2):133-147. http://dx.doi. org/10.1016/j.flora.2006.03.006

9. Marcysiak K, Boratyński A. Contribution to the taxonomy of Pinus uncinata (Pinaceae) based on cone characters. Plant Syst Evol. 2007;264(1-2):57-73. http://dx.doi. org/10.1007/s00606-006-0501-2

10. Boratynski A, Marcysiak K, Lewandowska A, Jasinska A, Iszkulo G, Burczyk J. Differences in leaf morphology between Quercus petraea and Q. robur adult and young individuals. Silva Fenn. 2008;42(1):115-124.

11. Huber H, Wiggerman L. Shade avoidance in the clonal herb Trifolium fragiferum: a field study with experimentally manipulated vegetation height. Plant Ecol. 1997;130(1):53-62.

12. Noda H, Muraoka H, Washitani I. Morphological and physiological acclimation responses to contrasting light and water regimes in Primula sieboldii. Ecol Res. 2004;19(3):331340. http://dx.doi.org/10.1111/j.1440-1703.2004.00642.x

13. Marchand FL, Kockelbergh F, van de Vijver B, Beyens L, Nijs I. Are heat and cold resistance of arctic species affected by successive extreme temperature events? New Phytol. 2006;170(2):291-300. http://dx.doi. org/10.1111/j.1469-8137.2006.01659.x

14. Baquedano F, Valladares F, Castillo F. Phenotypic plasticity blurs ecotypic divergence in the response of Quercus coccifera and Pinus halepensis to water stress. Eur J Forest Res. 2008;127(6):495-506. http://dx.doi.org/10.1007/ s10342-008-0232-8

15. Fletcher BJ, Press MC, Baxter R, Phoenix GK. Transition zones between vegetation patches in a heterogeneous Arctic landscape: how plant growth and photosynthesis change with abundance at small scales. Oecologia. 2010;163(1):4756. http://dx.doi.org/10.1007/s00442-009-1532-5

16. Wijk S. Performance of Salix Herbacea in an Alpine Snow-Bed Gradient. J Ecol. 1986;74(3):675. http://dx.doi. org/10.2307/2260390

17. Wijk S. Influence of climate and age on annual ahoot ancrement in Salix herbacea. J Ecol. 1986;74(3):685. http:// dx.doi.org/10.2307/2260391

18. Beerling DJ. Salix herbacea L. J Ecol. 1998;86(5):872-895. http://dx.doi.org/10.1046/j.1365-2745.1998.8650872.x

19. Rundgren $\mathrm{M}$, Beerling D. A Holocene $\mathrm{CO}_{2}$ record from the stomatal index of subfossil Salix herbacea L. leaves from northern Sweden. Holocene. 1999;9(5):509-513. http:// dx.doi.org/10.1191/095968399677717287

20. Beerling DJ, Rundgren M. Leaf metabolic and morphological responses of dwarf willow (Salix herbacea) in the sub-arctic to the past 9000 years of global environmental change. New Phytol. 2000;145(2):257-269. http://dx.doi. org/10.1046/j.1469-8137.2000.00582.x

21. Stamati K, Blackie S, Brown JWS, Russell J. A set of 
polymorphic SSR loci for subarctic willow (Salix lanata, $S$. lapponum and S. herbacea). Mol Ecol Notes. 2003;3(2):280282. http://dx.doi.org/10.1046/j.1471-8286.2003.00426.x

22. Stamati K, Hollingsworth PM, Russell J. Patterns of clonal diversity in three species of sub-arctic willow (Salix lanata, Salix lapponum and Salix herbacea). Plant Syst Evol. 2007;269(1-2):75-88. http://dx.doi.org/10.1007/ s00606-007-0578-2

23. Reisch C, Schurm S, Poschlod P. Spatial genetic structure and clonal diversity in an alpine population of Salix herbacea (Salicaceae). Ann Bot. 2007;99(4):647-651. http:// dx.doi.org/10.1093/aob/mcl290

24. Alsos IG, Alm T, Normand S, Brochmann C. Past and future range shifts and loss of diversity in dwarf willow (Salix herbacea L.) inferred from genetics, fossils and modelling. Global Ecol Biogeogr. 2009;18(2):223-239. http://dx.doi. org/10.1111/j.1466-8238.2008.00439.x

25. Pawłowski B. Flora Tatr. Rośliny naczyniowe. Warszawa: Polish Scientific Publishers PWN; 1956. (vol 1).

26. Tutin TG. Salicaceae. In: Tutin TG, Heywood VH, Burges NA, Valentine DH, Walters SM, Webb DA, editors. Flora Europaea. Cambridge: Cambridge University Press; 1964. p. 43-55. (vol 1).

27. Boratynska K. Chorologia i rejonizacja leśna brzozowatych (Betulaceae). Cz. II: Rola brzozowatych w poszczególnych regionach geograficznych. Arboretum Kórnickie. 1983;28:69-99.

28. de Groot WJ, Thomas PA, Wein RW. Betula nana L. and Betula glandulosa Michx. J Ecol. 1997;85(2):241-264.

29. Iversen J. The development of Denmark's nature since the last glacial. København: C.A. Reitzels Forlag; 1973.

30. Ingrouille M. Historical ecology of the British flora. London: Chapman \& Hall; 1995.

31. Ralska-Jasiewiczowa M, Goślar T, Madeyska T, Starkel L, editors. Lake Gościąż, Central Poland. A monographic study. Kraków: W. Szafer Institute of Botany, Polish Academy of Sciences; 1998.

32. Elkington TT. Introgressive hybridization between Betula nana L. and B. pubescens Ehrh. in north-west Iceland. New Phytol. 1968;67(1):109-118. http://dx.doi. org/10.1111/j.1469-8137.1968.tb05459.x

33. Wagner F, Neuvonen S, Kürschner WM, Visscher H. The influence of hybridization on epidermal properties of birch species and the consequences for palaeoclimatic interpretations. Plant Ecol. 2000;148(1):61-69.

34. Anamthawat-Jónsson K, Thórsson AT. Natural hybridization in birch: triploid hybrids between Betula nana and $B$. pubescens. Plant Cell Tiss Organ Cult. 2003;75(2):99-107.

35. Palme AE, Su Q, Palsson S, Lascoux M. Extensive sharing of chloroplast haplotypes among European birches indicates hybridization among Betula pendula, B. pubescens and B. nana. Mol Ecol. 2004;13(1):167-178. http://dx.doi. org/10.1046/j.1365-294X.2003.02034.x

36. Thórsson AT, Pálsson S, Sigurgeirsson A, AnamthawatJónsson K. Morphological variation among Betula nana (diploid), B. pubescens (tetraploid) and their triploid hybrids in Iceland. Ann Bot. 2007;99(6):1183-1193. http:// dx.doi.org/10.1093/aob/mcm060

37. Caseldine $\mathrm{CH}$. Changes of Betula in the Holocene record from Iceland - a paleoclimatic record or evidence for early Holocene hybridization. Rev Palaeobot Palynol. 2001;117:139-152.

38. Jónsson TH. Stature of sub-arctic birch in relation to growth rate, lifespan and tree form. Ann Bot. 2004;94(5):753-762. http://dx.doi.org/10.1093/aob/mch200

39. Białobrzeska M, Truchanowicz J. Badania systematycznobiometryczne nad rodzajem Betula L. ze Szczelińca w górach Stołowych. Rocznik Dendrologiczny. 1990;39:51-78.

40. Elven R, Karlsson T. Salix L. In: Jonsell B, editor. Flora Nordica. Stockholm: The Bergius Foundation; 2000. p. 117-188. (vol 1).

41. Beerling DJ, Terry AC, Hopwood C, Osborne CP. Feeling the cold: atmospheric $\mathrm{CO}_{2}$ enrichment and the frost sensitivity of terrestrial plant foliage. Palaeogeogr Palaeoclim Palaeoecol. 2002;182(1-2):3-13. http://dx.doi.org/10.1016/ S0031-0182(01)00449-7

42. Rundgren M, Björck S. Late-glacial and early Holocene variations in atmospheric $\mathrm{CO}_{2}$ concentration indicated by high-resolution stomatal index data. Earth Planet Sci Lett. 2003;213(3-4):191-204. http://dx.doi.org/10.1016/ S0012-821X(03)00324-8

43. Kovačić S, Nikolić T. Relations between Betula pendula Roth. (Betulaceae) leaf morphology and environmental factors in five regions of Croatia. Acta Biol Cracov. 2005;47(2):7-13. 